\title{
A Heparan Sulfate-Binding Cell Penetrating Peptide for Tumor Targeting and Migration Inhibition
}

\author{
Chien-Jung Chen, ${ }^{1}$ Kang-Chiao Tsai, ${ }^{1}$ Ping-Hsueh Kuo, ${ }^{1}$ Pei-Lin Chang, \\ Wen-Ching Wang, ${ }^{1,2}$ Yung-Jen Chuang, ${ }^{3,4}$ and Margaret Dah-Tsyr Chang ${ }^{1,4}$ \\ ${ }^{1}$ Institute of Molecular and Cellular Biology, National Tsing Hua University, Hsinchu 30013, Taiwan \\ ${ }^{2}$ Biomedical Science and Engineering Center, National Tsing Hua University, Hsinchu 30013, Taiwan \\ ${ }^{3}$ Institute of Bioinformatics and Structural Biology, National Tsing Hua University, Hsinchu 30013, Taiwan \\ ${ }^{4}$ Department of Medical Science, National Tsing Hua University, Hsinchu 30013, Taiwan
}

Correspondence should be addressed to Margaret Dah-Tsyr Chang; dtchang@life.nthu.edu.tw

Received 18 August 2014; Revised 31 October 2014; Accepted 14 November 2014

Academic Editor: Hao-Teng Chang

Copyright (C) 2015 Chien-Jung Chen et al. This is an open access article distributed under the Creative Commons Attribution License, which permits unrestricted use, distribution, and reproduction in any medium, provided the original work is properly cited.

\begin{abstract}
As heparan sulfate proteoglycans (HSPGs) are known as co-receptors to interact with numerous growth factors and then modulate downstream biological activities, overexpression of HS/HSPG on cell surface acts as an increasingly reliable prognostic factor in tumor progression. Cell penetrating peptides (CPPs) are short-chain peptides developed as functionalized vectors for delivery approaches of impermeable agents. On cell surface negatively charged HS provides the initial attachment of basic CPPs by electrostatic interaction, leading to multiple cellular effects. Here a functional peptide (CPPecp) has been identified from critical HS binding region in hRNase3, a unique RNase family member with in vitro antitumor activity. In this study we analyze a set of HS-binding CPPs derived from natural proteins including CPPecp. In addition to cellular binding and internalization, $\mathrm{CPP} e c p$ demonstrated multiple functions including strong binding activity to tumor cell surface with higher HS expression, significant inhibitory effects on cancer cell migration, and suppression of angiogenesis in vitro and in vivo. Moreover, different from conventional highly basic CPPs, CPPecp facilitated magnetic nanoparticle to selectively target tumor site in vivo. Therefore, CPPecp could engage its capacity to be developed as biomaterials for diagnostic imaging agent, therapeutic supplement, or functionalized vector for drug delivery.
\end{abstract}

\section{Introduction}

Carcinoma is a malignant cancer originating in the ectodermal and endodermal epithelial cells. Interaction between cell surface and microenvironment plays a crucial role in malignant tumor progression. Alterations of cell surface receptor, coreceptor, and adhesive protein expression are reported in various cancer types in vitro and in vivo [1-3]. Abnormal expression of cell surface molecules notably contributes to enhance tumor cell growth, survival, migration, and invasiveness [4]. Characterization of such alterations and development of novel agent for specific targeting are unmet medical need for early cancer diagnosis.

Glycosaminoglycans (GAGs) including heparan sulfate (HS), chondroitin sulfate (CS), keratan sulfate (KS), or dermatan sulfate (DS) are covalently attached to their core proteins to form proteoglycans. HS proteoglycan (HSPG) present in the extracellular matrix (ECM) provides structural frameworks to mediate cell-cell communication and function in growth factor-receptor binding [5, 6]. HSPGs are key players in modulating tumor progression processes including metastasis, angiogenesis, proliferation, and malignant transformation [4]. Thus, upregulation of cell surface HS may play an active and crucial role in directing malignant phenotype of cancer during different developmental stages.

Cell penetrating peptides (CPPs) are short-chain cationic and/or amphipathic peptides which may be internalized into living cells [7]. CPPs are able to mediate translocation of a conjugated cargo (e.g., anticancer therapeutics) across plasma membrane, providing an effective and nontoxic mechanism 
for drug delivery [8]. Most CPPs are rich in positively charged Arg and Lys residues and are internalized after initially interacting with cell surface negatively charged GAGs which cluster CPPs on outer membrane surfaces $[9,10]$.

CPPs might be potentially used in clinical procedures such as gene therapy and cancer therapy $[8,11]$. However, most CPPs are unfeasible for in vivo researches due to nonspecificity of their highly cationic characteristics. Cell surface negatively charged HS initializes the contact of CPPs, so particular HS binding CPPs might own mysterious sequence to exert multiple functions including HS binding, cellular binding, lipid binding, and in vivo tissue targeting activities. CPPecp is a recently identified CPP not only binding to negatively charged molecules including GAGs and lipids on cell surface in vitro but also targeting mucosal tissues in vivo [12-14]. In this study, we aim to collect and analyze the characteristics of HS-binding cell penetrating peptides derived from natural proteins. Besides, CPPecp itself falling in this classification has demonstrated multiple functions including in vitro tumor binding, tumor migration inhibition and angiogenesis inhibition activities, and in vivo cargo delivery to tumor site. Here, we provide more clues for the design of peptide therapeutics or intratumor delivery strategy by linking of a tumor targeting CPP. Furthermore, CPPecp might be a unique HS probe for cancer diagnosis to facilitate the quality of therapeutic index and molecular imaging in translational medicine.

\section{Materials and Methods}

2.1. Synthetic Peptides. Peptides CPPecp (NYRWRCKNQN) and $\mathrm{EDN}^{32-41}$ (NYQRRCKNQN) or CPPecp with $N$-terminally conjugated fluorescein isothiocyanate (FITC) or tetramethylrhodamine (TMR) were synthesized by Genemed Synthesis Inc. and their purities (>90\%) were assessed by analytical high-performance liquid chromatography. Peptide sequences were confirmed by matrix-assisted laser desorption/ionisation time-of-flight mass spectrometry in Genemed Synthesis Inc.

2.2. Flow Cytometry. Cells $\left(3.0 \times 10^{5} /\right.$ well $)$ were added into six-well plates and cultured in the indicated medium. After $24 \mathrm{~h}, 5 \mu \mathrm{M}$ FITC-CPPecp dissolved in medium was added into a well and the samples were incubated for $1 \mathrm{~h}$. Cells were then harvested, washed, and suspended in PBS. The fluorescent intensities of the cell samples were measured using a FACSCalibur flow cytometer (BD Biosciences, Franklin Lakes, NJ) and excitation and emission wavelengths of $488 \mathrm{~nm}$ and $515-545 \mathrm{~nm}$, respectively. The relative internalization of FITC-CPPecp was reported as the mean fluorescent signal for 10,000 cells.

2.3. Fluorescence Microscopy. CT-26 cells were cultured on coverslips $\left(5.0 \times 10^{3} /\right.$ coverslip $)$ in RPMI-1640. After $24 \mathrm{~h}$, cell samples were incubated with FITC or FITC-CPPecp at $37^{\circ} \mathrm{C}$ for $10 \mathrm{~min}$. Alternatively, CT-26 cells were pretreated with heparinase II ( $2.5 \mathrm{mU} / \mathrm{mL}$ ) (Sigma-Aldrich, Missouri,
USA) at $37^{\circ} \mathrm{C}$ for $2 \mathrm{~h}$ followed by treatment with $5 \mu \mathrm{M}$ TMR$\mathrm{CPPecp}$ at $37^{\circ} \mathrm{C}$ for $10 \mathrm{~min}$. The cells were then washed twice with PBS, fixed with $4 \%(\mathrm{w} / \mathrm{v})$ paraformaldehyde, and rinsed twice with PBS. The coverslips were mounted in a Vectashield antifade mounting medium with DAPI (Vector Labs). Inverted fluorescent microscopy was performed using Axiovert 135 (Carl Zeiss, Göttingen, Germany) to assess the distribution of the FITC-CPPecp or TMR-ECPecp in the cells.

2.4. In Vitro Cell Migration Assay. Effect of CPPecp on cell migration was assessed using a 24-well transwell plate inserted with incorporating polyethylene terephthalate filter membrane with $8 \mu \mathrm{m}$ pores (BD FalconTM Cell Culture Insert System).

Approximately $4 \times 10^{4}$ CT- 26 cells (obtained from ATCC, number: CRL-2638) were suspended in $200 \mu \mathrm{L}$ of serum-free RPMI-1640 medium (Sigma-Aldrich, Missouri, USA) and pretreated with $1.25,2.5,5$, and $12.5 \mu \mathrm{M}$ CPPecp or $\mathrm{EDN}^{32-41}$ at RT for $30 \mathrm{~min}$, and then seeded on the upper compartment of transwell insert membrane. The lower compartment of membrane containing $300 \mu \mathrm{L}$ 1\% FBS (Gibco/Invitrogen) RPMI-1640 medium was used as chemoattractant. After incubating at $37^{\circ} \mathrm{C}$ and $5 \% \mathrm{CO}_{2}$ for $18 \mathrm{~h}$, the migrated cells on the lower surface of membrane were fixed with $4 \%$ formaldehyde for $15 \mathrm{~min}$ and stained with $0.05 \%$ crystal violet for $20 \mathrm{~min}$. The nonmigrated cells on the upper surface of membrane were removed by cotton swab. Numbers of migrated cells were counted in a randomly selected microscopic field (100x) using inverted microscopy (Olympus CK40, Artisan Technology Group, Mercury Drive Champaign, USA).

Approximately $5 \times 10^{4}$ human umbilical vein endothelial cells (HUVECs) (obtained from BCRC, number: H-UV001) were suspended in $200 \mu \mathrm{L}$ complete EC medium (Gibco) containing 0,5 , or $12.5 \mu \mathrm{M} \mathrm{CPPecp} \mathrm{and} \mathrm{then} \mathrm{seeded} \mathrm{on}$ the upper compartment of filter. The lower compartment of filter contains $500 \mu \mathrm{L}$ complete EC medium with $20 \mathrm{ng} / \mathrm{mL}$ VEGF (R\&D) as stimulator. After incubating at $37^{\circ} \mathrm{C}$ and $5 \% \mathrm{CO}_{2}$ for $4 \mathrm{~h}$, the migrated cells on the lower surface of filter were fixed with $4 \%$ formaldehyde at RT for $15 \mathrm{~min}$ and stained with Hocechst at RT for $15 \mathrm{~min}$. The nonmigrated cells on the upper surface of filter were removed by cotton swab. Filter membrane of transwell insert was cut down and mounted with Fluoromount mounting medium (Sigma Aldrich, Missouri, USA). Numbers of migrated cells were counted in five randomly selected microscopic fields at magnification 100x using inverted fluorescent microscope (TE2000E, Nikon, Kanagawa, Japan) with a cooled CCD (Evolution VF, MediaCybernetics, Bethesda, MD).

The result was represented as mean \pm SD (standard deviation) of three independent experiments. Statistically significant differences were analyzed using unpaired Student's $t$-test. Asterisks showed level of statistical significance: ${ }^{*} P<$ $0.05 ; P<0.01 ;{ }^{* * *} P<0.001$ compared with control.

2.5. Zebrafish Angiogenesis Model. Tg(kdr:EGFP) zebrafish, a well-studied model for vascular embryogenesis [15], was performed to assess the effects of СРPecp on angiogenesis. The $\operatorname{Tg}(\mathrm{kdr}$ :EGFP) (kindly provided by Dr. Yung-Jen 
Chuang's lab at NTHU) is a transgenic zebrafish line that expresses eGFP driven by the kdr promoter in vasculature endothelial cells during zebrafish embryogenesis, which can serve as an in vivo angiogenesis model for drug screening [16]. Fertilized eggs were generated from adult mating pairs and incubated at $28.5^{\circ} \mathrm{C}$ in a recirculating aquaculture system. The zebrafish embryos were separately injected with 6.3 or $31.5 \mathrm{ng}$ CPPecp ( $4.6 \mathrm{~nL} ; 4.56$ or $22.8 \mathrm{pmol}$ ) into yolk sac at $60 \mathrm{~h}$ postfertilization (hpf), and PBS injection was set as control (16-20 zebrafish were used for each treatment condition). After incubating for $24 \mathrm{~h}$, development of subintestinal vessels (SIV) pattern in the zebrafish yolk sac was observed and imaged by inverted fluorescent microscope (TE2000E, Nikon, Kanagawa, Japan) with a cooled CCD (Evolution VF, MediaCybernetics, Bethesda, MD).

2.6. Animal Model. All work performed with animals was approved by the Institutional Animal Care and Use Committee at the National Tsing Hua University. Five-week-old female Balb/c mice (supplied by National Laboratory Animal Center, Taiwan) were housed in laboratory animal room at National Tsing Hua University and allowed to adapt to new surrounding for about seven to fourteen days. Animal rooms had a twelve-to-twelve-hour light-dark/day-night cycle and were maintained at constant temperature and humidity. For establishment of tumor-bearing mouse model, CT-26, a mouse colon carcinoma cell was suspended at a density of $1 \times 10^{6}$ cells in $100 \mu \mathrm{L}$ PBS containing 50\% Matrigel (BD Biosciences, San Jose, CA) and subcutaneously injected into the right back of each mouse. Once subcutaneous tumor volumes grew up to $100 \mathrm{~mm}^{3}$, all mice were subjected to various treatments. At the end of the experiment, the mice were sacrificed by $\mathrm{CO}_{2}$ narcosis. All of the organs including kidney, liver, spleen, trachea, lung, intestine, heart, pancreas, stomach, and tumor of these mice were taken, fixed with paraformaldehyde, embedded in paraffin, and sliced into $5 \mu \mathrm{m}$ tissue slides for Prussian blue staining.

\subsection{Magnetic Nanoparticle Conjugated CPPecp and Prussian} Blue Staining. To analyze in vivo tissue targeting of CPPecp, we have conjugated CPPecp onto a dextran-coated $\mathrm{Fe}_{3} \mathrm{O}_{4}$ type of magnetic nanoparticle (MNP) to form MNP-conjugated СРPecp (MNP-CPPecp) with a mean diameter of $59.3 \mathrm{~nm}$ (kindly provided by MagQu. Co., Ltd.) [17]. CT-26 tumorbearing mouse was utilized to investigate biodistribution of MNP-CPPecp and Prussian blue staining was employed to demonstrate ferric iron in mouse tissues. The CT-26 tumorbearing mouse was intravenously injected with $150 \mu \mathrm{L}$ MNP$\mathrm{CPPecp}(0.06 \mathrm{emu} / \mathrm{g})$ and sacrificed by $\mathrm{CO}_{2}$ narcosis at a time point of 3, 6, 12, and $24 \mathrm{~h}$ after administration. The kidney, heart, liver, spleen, stomach, pancreas, small intestine, large intestine, trachea, lung, and tumor of mice were taken, fixed with paraformaldehyde, embedded in paraffin, and sectioned into $5 \mu \mathrm{m}$ thick tissue slides, following by deparaffinizing in xylene solution (J. T. Baker Phillipsburg, NJ, USA) and serially rehydrating with $100 \%, 95 \%, 85 \%, 75 \%$, and $50 \%$ alcohol. The slides were continuously immersed in working solution (20\% hydrochloric acid and $10 \%$ potassium ferrocyanide
(Sigma, MO, USA) solution mixture, 1:1 volume ratio) at room temperature for $30 \mathrm{~min}$ and then counterstained with fast nuclear red (Sigma, MO, USA) at RT for 5 min. After dehydration through $95 \%$ and $100 \%$ alcohol and clearing with xylene, each slide was finally covered with coverslip. Tissue images were digitized using light microscope (Eclipse E400, Nikon) with digital microscopy camera (AxioCam ICc 5, ZEISS).

\section{Results and Discussion}

3.1. Heparan Sulfate Binding Cell Penetrating Peptides Derived from Natural Proteins. Heparan sulfate (HS) serves as the initial anchoring site for many CPPs through electrostatic interactions between negatively charged sulfates or carboxyl groups and basic amino acids Arg as well as Lys [18]. Till now 27 CPPs from natural proteins including 14 viral proteinderived peptides, 7 animal homeostatic modulator-derived peptides, 3 antimicrobial peptides, and 3 toxin-derived peptides have been demonstrated or predicted to be able to interact with cell surface HS and penetrate cross the plasma membrane. In silico secondary structures of all 27 HS-binding CPPs were predicted by Network Protein Sequence Analysis [19]. As shown in Table 1, 17 peptides including CPPs 2-6, 812,15 , and $18-23$ exist as $\alpha$ helix (H). Seven peptides including CPPs $1,7,13,14,16,17$, and 24 form random coil (C). CPP 23 exists as $\beta$ sheet (E), and CPPs 26 and 27 exist as mixed $\alpha$ helix (H) with $\beta$ sheet (E) structures. Among 27 CPPs seventeen structures have been validated by in vitro $3 \mathrm{D}$ structures deposited in Protein Data Bank (Table 1, underline) [20]. All 14 viral protein-derived CPPs are highly cationic (high pI values) with 10 peptides forming $\alpha$ helix and 4 existing as random coil, penetrating cells through direct translocation [21-24] and lipid raft-mediated endocytosis [25-29]. Most of the 7 animal homeostatic modulator-derived CPPs may be internalized into cytosol through HS-mediated and energydependent endocytosis, among which 5 animal proteinderived peptides are demonstrated to possess either $\alpha$ helix or $\beta$ sheet to interact with the plasma membrane, while our $\mathrm{CPP} e c p$ and apolipoprotein $\mathrm{B}$ binding domain are unique such that they hold random coil structures in this category. As for 3 antimicrobial peptides, all of them are suggested to interact with cell surface HS and penetrate membrane barrier via energy-dependent endocytosis. LL-37 holds high level of $\alpha$ helix, SynB1 possesses $\beta$ sheet, and SynB3 retains random coil structures [30-32]. For the last category toxinderived CPPs, bovine prion-derived bPrPp forming $\alpha$ helix and mixed $\alpha$ helix with $\beta$ strand are distributed in the internal region of venom-derived crotamine, and scorpion toxinderived maurocalcine [33-36].

Previous researches have shown that the interactions between the positively charged peptide and highly negatively charged membrane components, such as the GAG moieties of cell surface proteoglycans, play a crucial role in the overall process of cellular permeability of highly basic or amphipathic CPPs [37]. Although this investigation may also reflect nonspecific electrostatic interactions between these 


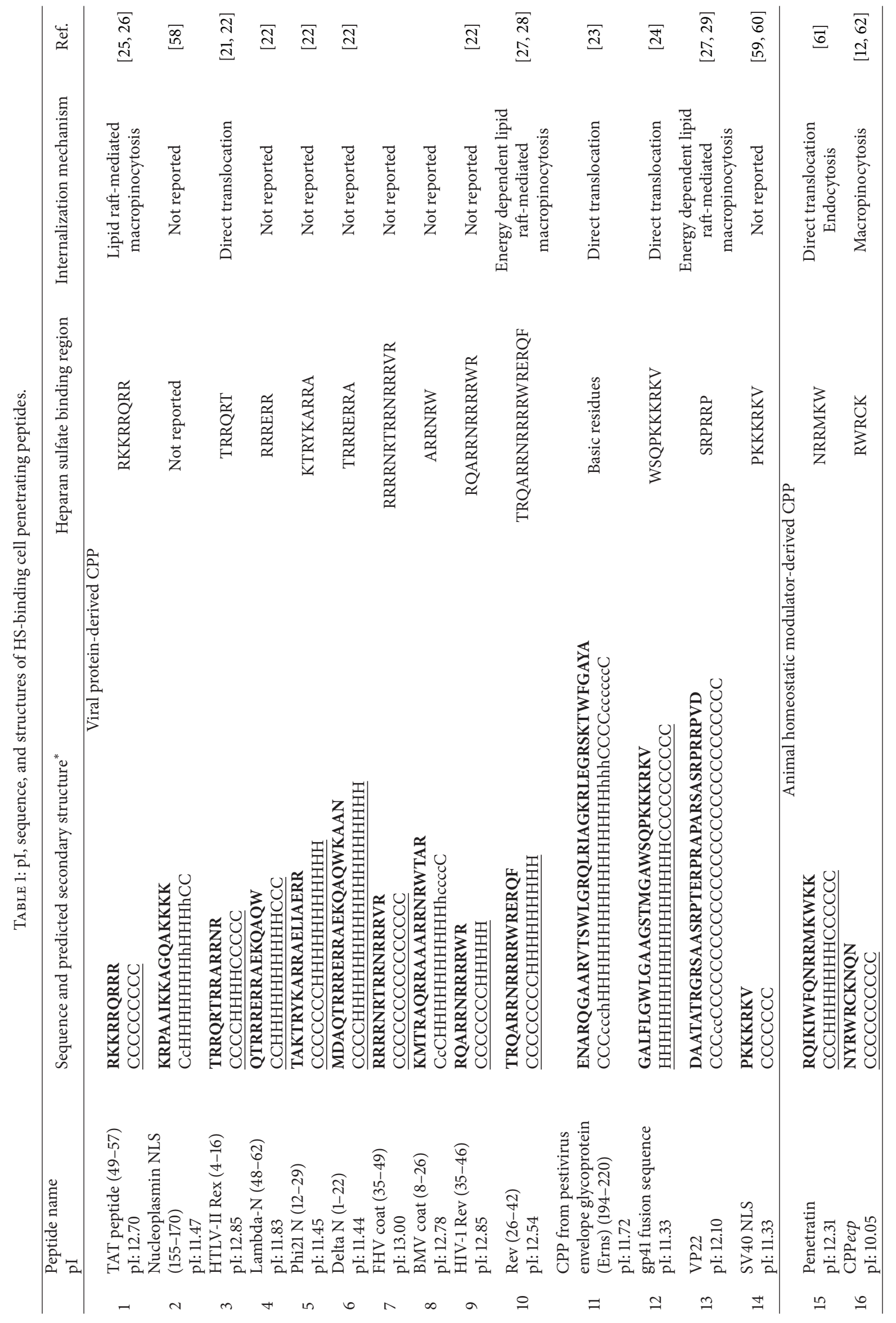




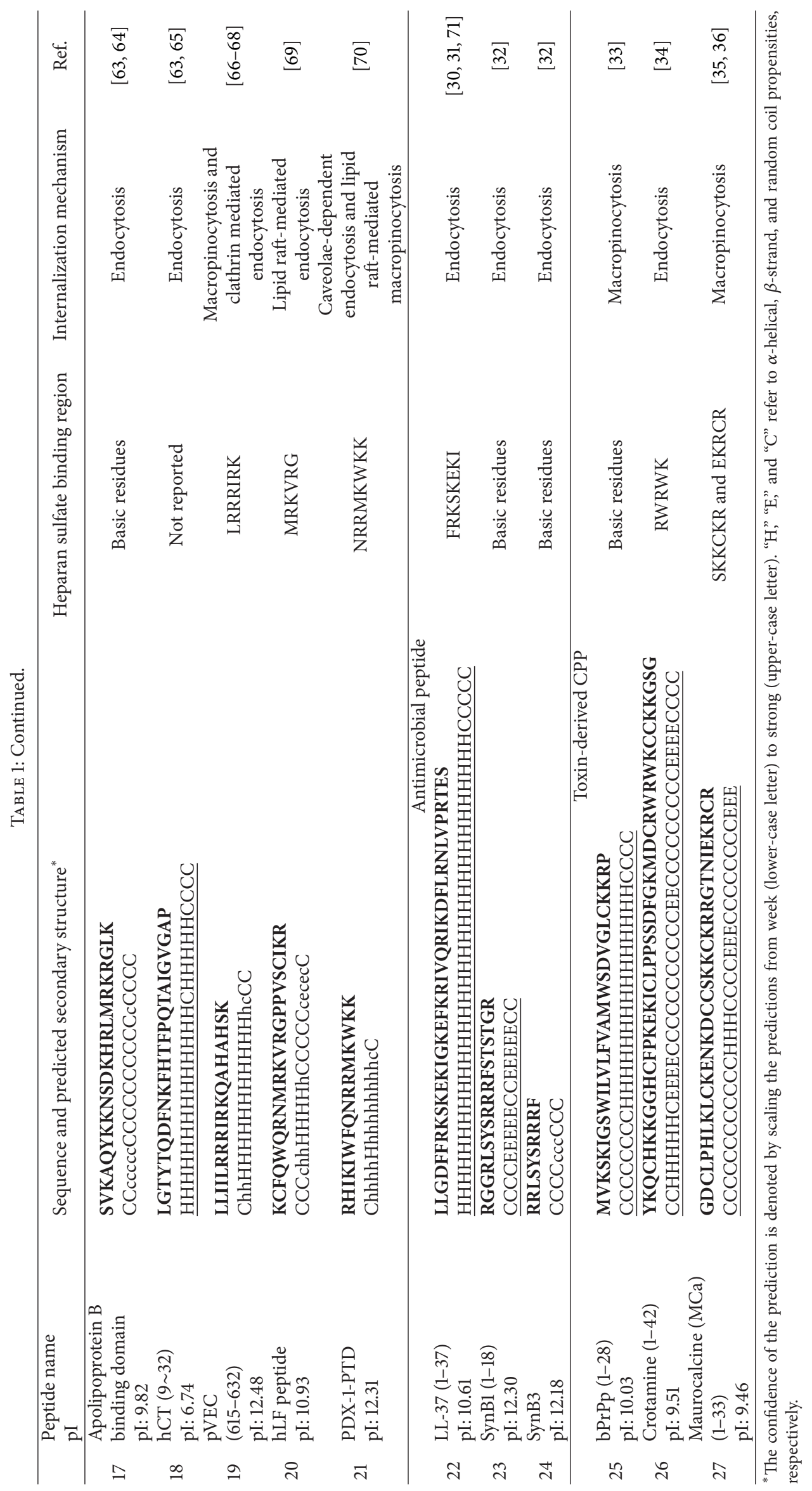


basic peptides and HS, it has been characterized that negatively charged heparin more effectively blocks uptake of CPPs than other soluble GAGs such as CS and hyaluronic acid [38], likely suggesting that there might be some structural requirements involved in the strong interaction between CPP and HS. In Table 1, 19 of these 27 HS-binding CPPs generally possess conventional heparin binding sequences such as $\mathrm{XBBXB}$ and $\mathrm{XBBBXXBX}$ where $\mathrm{B}$ is a basic amino acid and $\mathrm{X}$ represents a random amino acid, and they can also be divided into cationic and amphipathic groups. Most viral factorderived peptides are basic amino acid-rich. For example, cationic TAT is an extensively used CPP rich in Arg and can interact with sulfated proteoglycans and negatively charged phospholipids on the cell membrane [25]. It should be noted that although 10-amino acid CPPecp is almost equal size to 9residue TAT and 10-residue SynB3, the features of TAT and SynB3 are quite different from CPPecp. Both TAT derived from viral protein and SynB3 belonging to antimicrobial peptide are highly cationic peptides with high $\mathrm{pI}$ values above 12, while our newly identified CPPecp containing only $2 \mathrm{Arg}$ and 1 Lys in a total of 10 amino acids is amphipathic with a pI value of 10.05 . Interestingly, the proportion of basic residues in amphipathic crotamine $(26 \%)$ is close to CPPecp (30\%). "RWRCK" motif of CPPecp was previously predicted as a unique functional pattern in all $13 \mathrm{hRNaseA}$ family members employing Reinforced Merging for Unique Segments system (ReMUS) [39]. Another peptide CyLoP-1 (CRWRWKCCKK) derived from crotamine also exhibited efficient intracellular delivery activity. In both cases positively charged residues conducting electrostatic interaction and aromatic Trp exerting transient membrane destabilization were essential to maintain CPP functionality [40, 41]. Taken together, a similar motif "RWRXK" shown on the loop, where $\mathrm{X}$ might be a random amino acid, is present in both CPPecp and crotamine, suggesting that combination of positively charged residues and nonpolar aromatic residues, especially Trp, might provide a design rationale for novel amphipathic cell penetrating peptides.

\subsection{Cellular Binding of CPPecp to Tumor Cell with Higher} HS Expression Level. Heparan sulfate (HS) is reported to be overexpressed in several tumors $[42,43]$, while HSPG profiles on different tumor cell surface are largely unclear. Here a mouse colon cancer CT-26 cell line was used for in vitro and in vivo analyses. Cellular binding activity of CPPecp and HS expression level on cell surface of CT-26 cells were accessed for quantitative analysis employing flow cytometry and fluorescent microscopy with fluorescencelabeled CPPecp FITC-CPPecp and an anti-HS monoclonal antibody recognizing an epitope of $N$-sulfated glucosamine on membrane HS (US Biological, Swampscott, MA, USA). Figure 1(a) showed significant FITC-CPPecp binding activity to CT-26 cells, which correlated well with significantly higher HS expression (Figure 1(b)). In addition, $5 \mu \mathrm{M}$ FITC-CPPecp rapidly and efficiently internalized into CT-26 cells within $10 \mathrm{~min}$ as analyzed by fluorescent microscopy (Figure 1(c)). To further address the importance of HS for CPPecp anchor in the absence of autofluorescence background, removal of cell surface HS by heparinase was carried out along with CPPecp labeled with tetramethylrhodamine (TMR). CT-26 cells were incubated in medium with $(+)$ or without $(-)$ heparinase II for $2 \mathrm{~h}$ and then treated with $5 \mu \mathrm{M}$ TMRCPPecp for $10 \mathrm{~min}$. TMR-CPPecp rapidly and efficiently bound to CT-26 cell surface (Figure 1(d), upper panel), while removal of cellular HS led to significant reduction in CPPecp attachment (Figure 1(d), lower panel). Taken together, our HS-binding CPPecp possessed strong binding activity to tumor cell surface with higher HS expression, while depletion of cell surface HS abolished such highly selective binding activity of CPPecp to tumor cells.

\subsection{Effect of CPPecp on Migration of Mouse Colon Carcinoma} Cell. It has been shown that HSPGs may modulate cell migration by interacting with growth factors or chemokines and drives cell migrate toward specific stimuli [44]. Since CPPecp with a novel heparin-binding motif in ECP has already been identified to possess high recognition activity to cellular surface HSPG and penetration activity into cells [12], here whether CPPecp might modulate cancer cell migration through interaction with HSPG was further investigated using in vitro transwell migration assay, while $\mathrm{EDN}^{32-41}$, a 10amino acid peptide derived from comparable sequence motif of human RNase2 (EDN), possessing a conventional heparinbinding motif was also analyzed as a control. Figure 2 (black bar) showed that migration activity of CT-26 cell was significantly inhibited by CPPecp in a dose-dependent manner such that it decreased to $83 \%, 71 \%, 56 \%$, and $54 \%$ upon treatment with $1.25,2.5,5$, and $12.5 \mu \mathrm{M}$ CPPecp, respectively. Yet treatment with $1.25,2.5$ and $5 \mu \mathrm{M} \mathrm{EDN}^{32-41}$ could not inhibit migration activity of CT-26 cells, and presence of higher concentration of $\mathrm{EDN}^{32-41}(12.5 \mu \mathrm{M})$ decreased $33 \%$ tumor migration (Figure 2, gray bar). These results indicated that CPPecp containing core RWRCK motif, rather than containing known heparin-binding motif, inhibited CT-26 cell migration across the membrane in vitro. It has been reported that cancer migration was inhibited by antagonism of $\mathrm{HS}$ side chains. For example, A5G27 peptide derived from laminin $\alpha 5$ globular domain recognizes HS side-chains of CD44 variant 3 and blocks bioactivity of fibroblast growth factor-2 (FGF2). It significantly inhibits FGF-2-induced WiDr colon cancer cell migration and invasion [45]. Collectively, inhibitory effect of CPPecp on cancer cell migration is possibly arisen from interaction with cell surface HS.

\subsection{Effects of CPPecp on Migration of Vascular Endothelial} Cell. Cell surface HS proteoglycan (HSPG) serves as a coreceptor to coordinate binding of vascular endothelial growth factor (VEGF) toward its receptor. It has been reported to be associated with angiogenesis [46, 47]. However, vascular endothelial cell migration is a crucial step in formation of new blood vessel and tumor angiogenesis [48]. To test the hypothesis that CPPecp interacting with cell surface HSPGs also affected angiogenesis, a common model cell line human umbilical vein endothelial cell (HUVEC) was used for in vitro transwell migration assay. Figure 3 indicated that VEGFinduced HUVEC migration was restored by cotreatment 


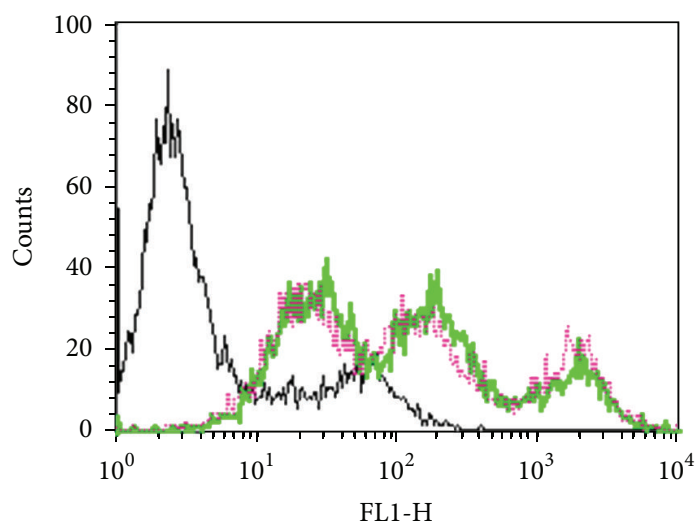

(a)
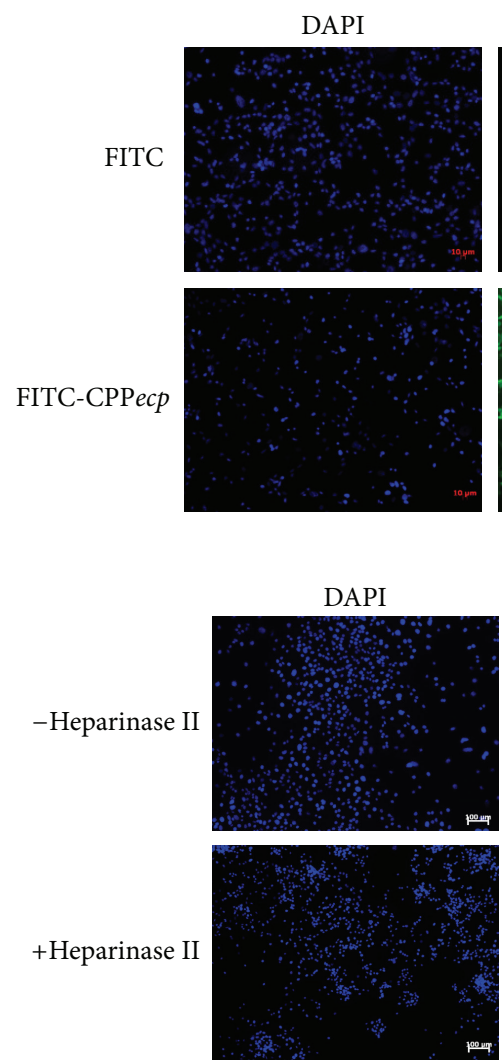

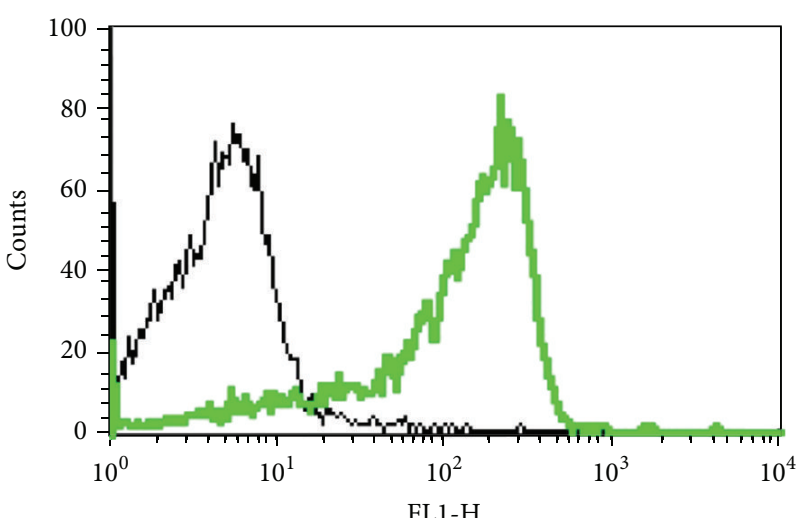

(b)
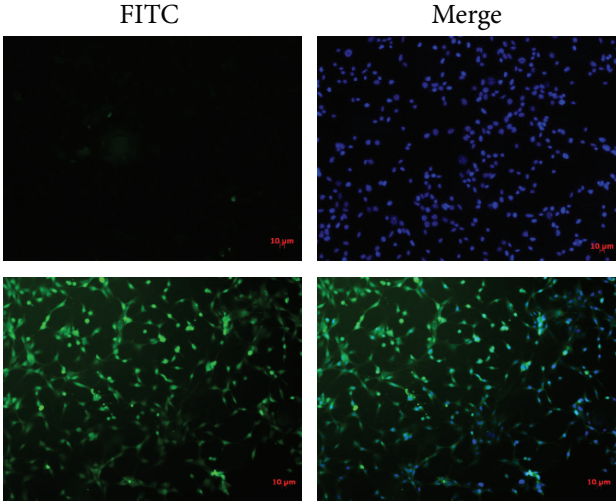

(c)
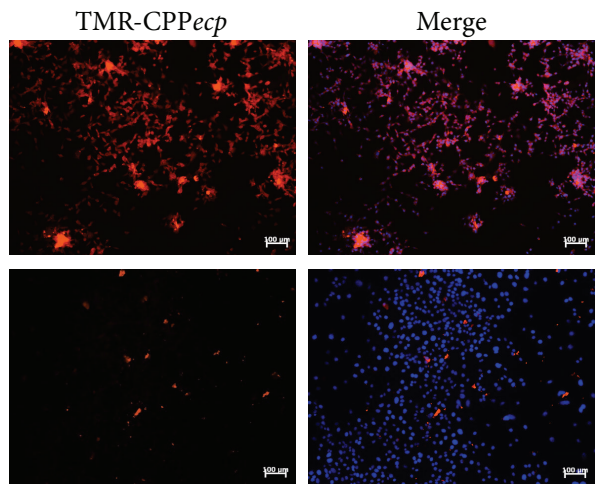

(d)

Figure 1: Effect of surface HS level on CPPecp binding to CT-26 cells. (a) CT-26 cells were preincubated at $4{ }^{\circ} \mathrm{C}$ for 30 min and then incubated with $5 \mu \mathrm{M}$ FITC-CPPecp for $1 \mathrm{~h}$. The cells were washed twice with $500 \mu \mathrm{L}$ PBS, trypsinized at $37^{\circ} \mathrm{C}$ for 15 min, suspended in $500 \mu \mathrm{L}$ PBS, and subjected to flow cytometry. (b) CT-26 cells were stained with anti-HS monoclonal antibody (10E4) at $4^{\circ} \mathrm{C}$ for $1 \mathrm{~h}$, washed twice with $500 \mu \mathrm{L}$ PBS, and hybridized with FITC-conjugated anti-mouse secondary antibody at $4^{\circ} \mathrm{C}$ for $1 \mathrm{~h}$. After being washed twice with $500 \mu \mathrm{L}$ PBS, cells were suspended in $500 \mu \mathrm{L}$ PBS and subjected to flow cytometry. (c) CT-26 cells were treated with $5 \mu \mathrm{M}$ FITC-CPPecp at $37^{\circ} \mathrm{C}$ for $10 \mathrm{~min}$. Uptake of FITC-CPPecp by CT-26 cells was examined by fluorescent microscopy. FITC was set as a negative control. DAPI staining of cells indicated intact nucleus. Scale bars in panel represented $10 \mu \mathrm{m}$. Green, FITC-labeled CPPecp; blue, DAPI (nucleus). (d) CT-26 cells were pretreated with or without heparinase II $(2.5 \mathrm{milliunit} / \mathrm{mL})$ at $37^{\circ} \mathrm{C}$ for $2 \mathrm{~h}$ followed by treatment with $5 \mu \mathrm{M}$ TMR-CPPecp at $37^{\circ} \mathrm{C}$ for $10 \mathrm{~min}$. Uptake of TMR-CPPecp by CT-26 cells was examined by fluorescence microscopy. TMR-CPPecp bound on CT-26 tumor cell DAPI staining of cells indicated intact nucleus. Scale bars in panel represented $10 \mu \mathrm{m}$. Red, TMR-labeled CPPecp; blue, DAPI (nucleus). 


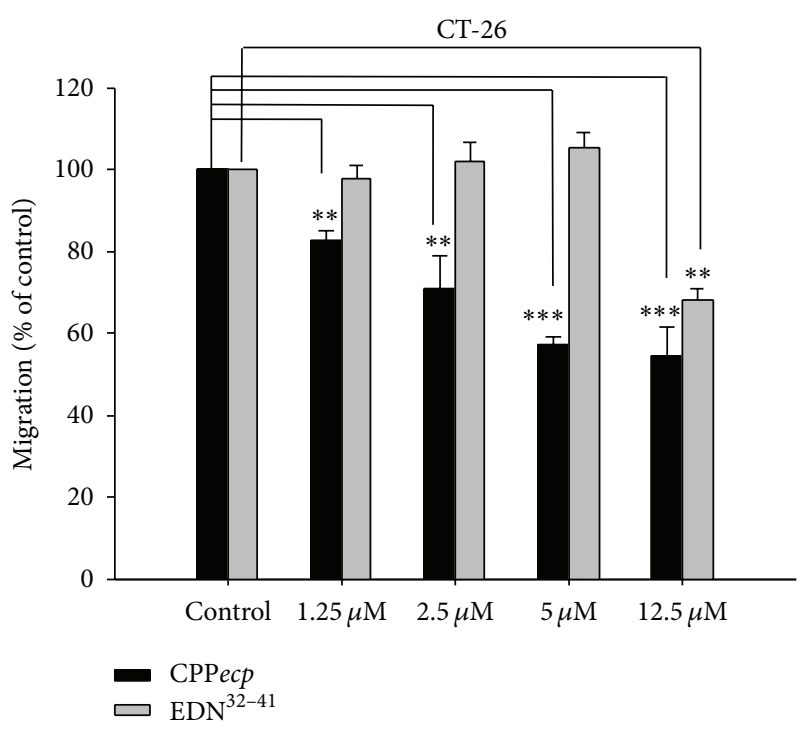

FIGURE 2: Inhibitory effect of CPPecp on CT-26 cell migration. CT-26 cells were pretreated with CPPecp or $\mathrm{EDN}^{32-41}$ at indicated concentration in serum-free RPMI-1640 medium at room temperature for $30 \mathrm{~min}$ and then seeded onto the upper side of transwell insert membrane at $37^{\circ} \mathrm{C}$ for $18 \mathrm{~h}$. Number of migrated cells without $\mathrm{CPP} e c p$ or $\mathrm{EDN}^{32-41}$ treatment was set as $100 \%$. The data represents means $\pm \mathrm{SD}$ (standard deviation) of three independent experiments. ${ }^{*} P<0.05 ;{ }^{* *} P<0.01 ;{ }^{* * *} P<0.001$ compared with control.

with 5 or $12.5 \mu \mathrm{M}$ CPPecp, leading to, respectively, $77 \%$ and $64 \%$ migration activity. This result indicated that СРРеcp could inhibit VEGF-induced HUVEC migration. Likewise, the CD44-binding peptide A5G27 derived from laminin $\alpha 5$ globular domain inhibits FGF-induced angiogenesis in Chick CAM Assay [49]. Moreover, an HS-binding peptide 6a-P, corresponding to the HSPG binding domain of VEGF, binds to HSPG and affects interaction between VEGF and HSPG [50]. It interferes with angiogenesis by inhibiting VEGF-induced HUVEC migration and binding of VEGF to HUVEC. As a result, involvement of our CPPecp in angiogenesis may be attributed to interaction with cell surface HSPG.

3.5. Effects of CPPecp on Angiogenesis during Embryonic Development of Zebrafish. Cell surface HSPGs serve as a coreceptor to coordinate binding of VEGF toward its receptor and have been reported to be associated with angiogenesis $[46,47]$. Tg(kdr:EGFP) zebrafish, a well-studied model for vascular embryogenesis, has been used as model for drug screening and angiogenesis studies [51, 52]. It was thus utilized to investigate CPPecp effects on in vivo embryonic angiogenesis by injecting $4.6 \mathrm{~nL}$ of 4.56 or 22.8 pmol CPPecp or PBS (control) into yolk sac of zebrafish at $60 \mathrm{~h}$ postfertilization (hpf), and the development of subintestinal vessel (SIV) pattern (Figure 4(a), SIV networks are indicated with red rectangle) at $24 \mathrm{~h}$ postinjection (hpi) was monitored with images by inverted fluorescent microscope. Here 1620 zebrafish were tested for each treatment group. The observed SIV patterns of zebrafish were divided into three groups according to growth level of SIV: normal, mildly inhibited, and severely inhibited phenotypes (Figure 4(b)). In the normal phenotype SIV developed as smooth basketlike pattern with 5-6 arcades. Both mild and severe inhibition phenotypes could be further classified as ectopic SIV pattern, in which SIV exhibited tortuous network and was unable to demonstrate complete basket-like pattern that normal phenotype developed. However, severe inhibition phenotype displayed more incomplete SIV network than mild inhibition phenotype did. In contrast, the zebrafish injected with CPPecp appeared to be tortuous, in which SIV pattern shrank significantly as compared with that of PBS control (Figure 4(c)). Figure 4(d) illustrated quantitative analysis data in which percentage of ectopic SIV phenotype (mildly inhibited phenotype plus severely inhibited phenotype) rose from $39.6 \%$ up to $49.2 \%$ and $52.6 \%$ upon injection with 4.56 and 22.8 pmol CPPecp, respectively. Moreover, severely inhibited SIV phenotype increased from $11.1 \%$ up to $26.2 \%$ and $32.4 \%$ upon injection with 4.56 and $22.8 \mathrm{pmol}$, respectively. In other words, percentage of severely inhibited phenotype in ectopic phenotype of zebrafish increased from $27.3 \%$ (control) up to $52.3 \%$ and $60.7 \%$ upon injection with 4.56 and 22.8 pmol CPPecp, respectively (Figure 4(e)). These data revealed that our CPPecp possessed antiangiogenesis activity in inhibiting SIV growth of zebrafish. As a result, involvement of CPPecp in angiogenesis may be attributed to interaction with cell surface HS. CPPecp is the first antiangiogenic peptide deciphered in embryonic development of zebrafish.

3.6. Time-Dependent Biodistribution of MNP-CPPecp in CT26 Tumor-Bearing Mouse. To better understand biodistribution of our HS-binding СРPecp in vivo, СРРecp was conjugated with well-dispersed $\mathrm{Fe}_{3} \mathrm{O}_{4}$ magnetic beads (59.3 $\mathrm{nm}$ for diameter) to form magnetic nanoparticle-conjugated CPPecp (MNP-CPPecp). CT-26 tumor-bearing mice were intravenously injected with MNP-CPPecp (0.06 emu/g) and sacrificed at different time point after administration (Figure 5(a)). MNP-CPPecp signal was detected using Prussian blue staining to indicate ferric iron in tissue section (blue color). Figure 5(b) indicated that stainable ferric iron (blue color as indicated by yellow arrow) was barely detectable in trachea, heart, and large intestine at all indicated time points, and so did other tissues including stomach, pancreas and kidney (data not shown). The MNP-CPPecp mainly accumulated in liver tissues from $3 \mathrm{~h}$ up to $24 \mathrm{~h}$ owing to uptake and removal by macrophages of reticuloendothelial system, which played a role in clearance of external substance in liver $[53,54]$. Interestingly, Prussian blue staining signals in CT-26 tumor section suggested MNP-CPPecp accumulation from $12 \mathrm{~h}$ to $24 \mathrm{~h}$, whereas MNP signal was only detected in liver at $24 \mathrm{~h}$. One recent report showed that exendin- 4 peptide-conjugated superparamagnetic iron oxide nanoparticles were inevitably accumulated in liver tissue, suggesting that a nanoparticle might unavoidably be captured by this metabolic organ [55]. However, it is worth noting that CPPecp has potential to target colon carcinoma in vivo, suggesting 
Control

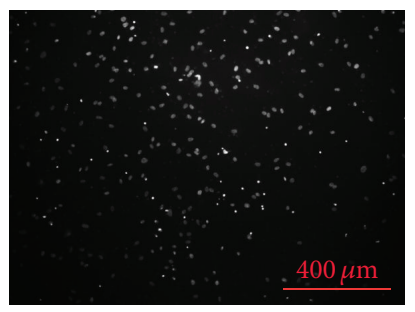

$20 \mathrm{ng} / \mathrm{mL}$ VEGF

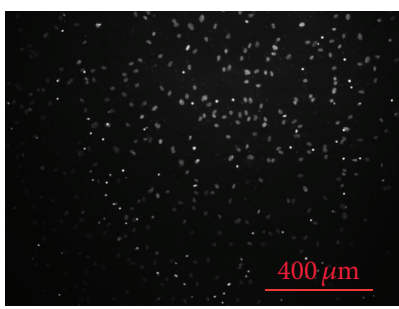

$20 \mathrm{ng} / \mathrm{mL}$ VEGF + $5 \mu \mathrm{M} \mathrm{CPPecp}$

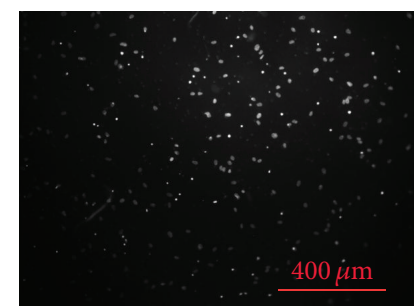

(a)

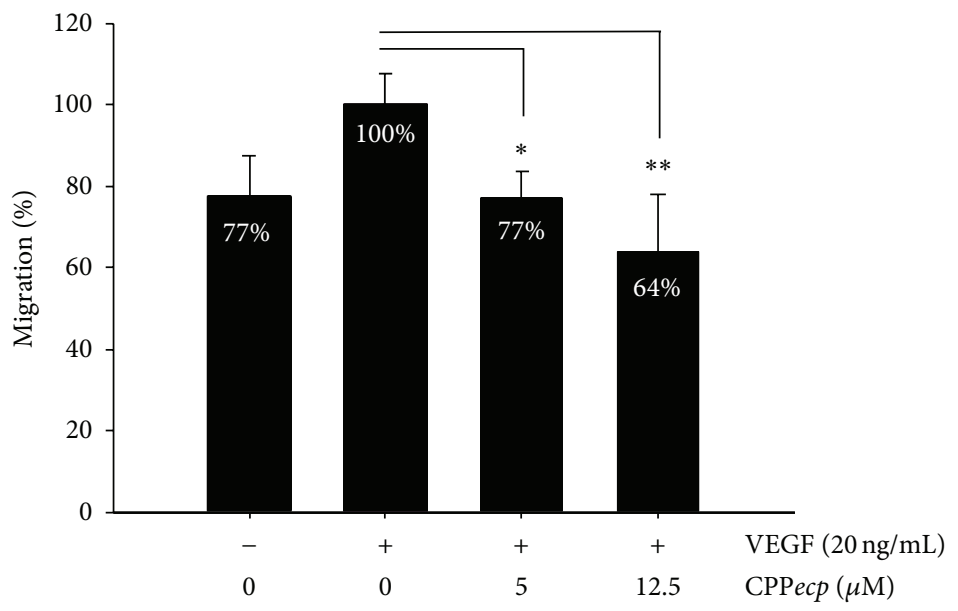

(b)

FIGURE 3: Inhibitory effect of CPPecp on HUVEC migration. HUVECs were seeded onto the upper side of transwell insert membrane containing CPPecp at indicated concentration at $37^{\circ} \mathrm{C}$ for $4 \mathrm{~h}$. The lower side of transwell was filled with complete EC medium supplementing with $20 \mathrm{ng} / \mathrm{mL}$ VEGF. Migrated cells on the lower surface of transwell insert membrane were stained with Hoechst (a). Percentage of migrated cells in the presence of VEGF and set as 100\% (positive control). Alternation of HUVEC migration activity in the presence of VEGF and various concentrations of CPPecp were quantified as compared with positive control (b). The data represents means \pm SD (standard deviation) of three independent experiments. ${ }^{*} P<0.05{ }^{* *} P<0.01 ;{ }^{* * *} P<0.001$ compared with control. Magnification: $100 \mathrm{x}$. Scale bar: $400 \mu \mathrm{m}$.

that $\mathrm{CPPecp}$ might be applied for a potent carrier for drug delivery.

3.7. Heparan Sulfate-Binding Cell Penetrating Peptide for Tumor Targeted Strategy. Although CPPs as noninvasive agents have promising biomedical potential for molecular delivery, they are mostly unfeasible for in vivo researches due to nonspecificity of their highly cationic characteristic such as TAT peptide. Due to high uptake rates in vitro and relatively low specificity in vivo of most CPPs, conventional CPPs would be designed for topical applications in CPP-based delivery (Table 1). Further analysis of natural protein-derived CPPs revealed that 5 CPPs exerted in vitro tumor suppression as well as cell internalization activities (Table 2). Although TAT peptide (46-57) demonstrated antiangiogenesis and apoptosis-inducing activities, TAT peptide was proved to show low target specificity in vivo [56]. Distinct from conventional highly cationic CPPs, 4 amphipathic CPPs including CPPecp, crotamine, NFL-TBS (40-63), and p28 peptides demonstrated unique tumor targeting activity in vivo. Even though specific protein receptors for CPPecp and crotamine remain to be investigated, HSPG acting as coreceptor is indispensable for the translocation of CPPecp and crotamine $[12,34]$. In addition, both CPPecp and crotamine targeted highly proliferating cells such as tumor tissues [14, 57]. Interestingly, a motif decorating a hydrophilic aromatic amino acid participating in membrane permeation between two arginines (RWR) appeared to be conserved in both CPPecp and crotamine, leading to similar characteristics of these 2 multifunctional HS-binding CPPs. Therefore, amphipathic CPPs might own promising potential to be designed as peptide-based drugs. In particular, HS-binding CPPs are suitable drug carriers for in vivo application in delivery of functional therapeutics.

\section{Conclusions}

CT-26 colon tumor cells revealed high CPPecp binding activity due to high HSPG expression on cell surface. CPPecp displays not only significantly inhibitory effects on CT-26 cancer migration and angiogenesis in vitro but also antiangiogenesis activity during zebrafish embryogenesis in vivo. Moreover, covalent linkage of СРPecp to magnetic nanoparticle shows potential for in vivo targeting to a subcutaneous CT-26 

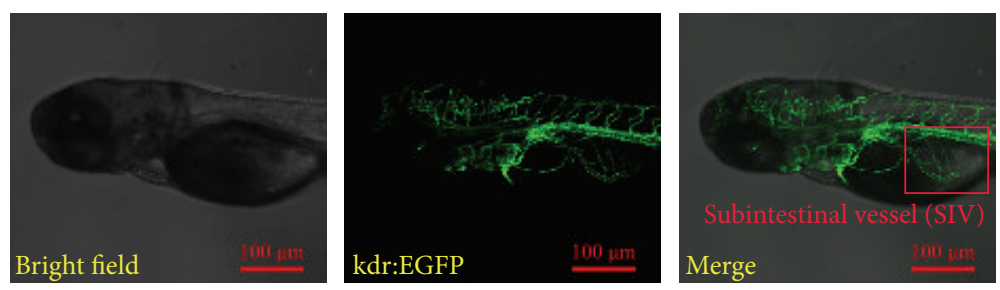

(a)
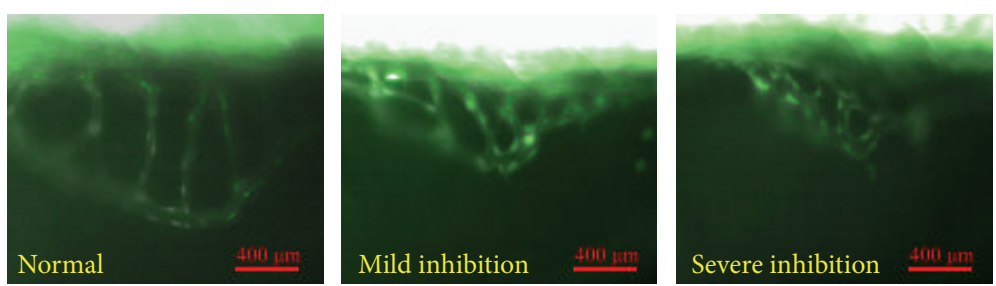

(b)
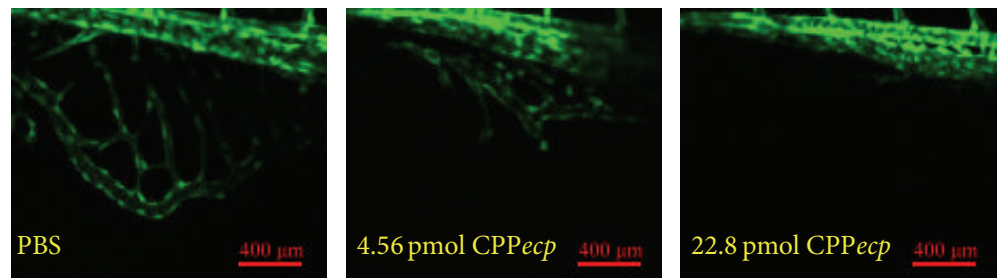

(c)
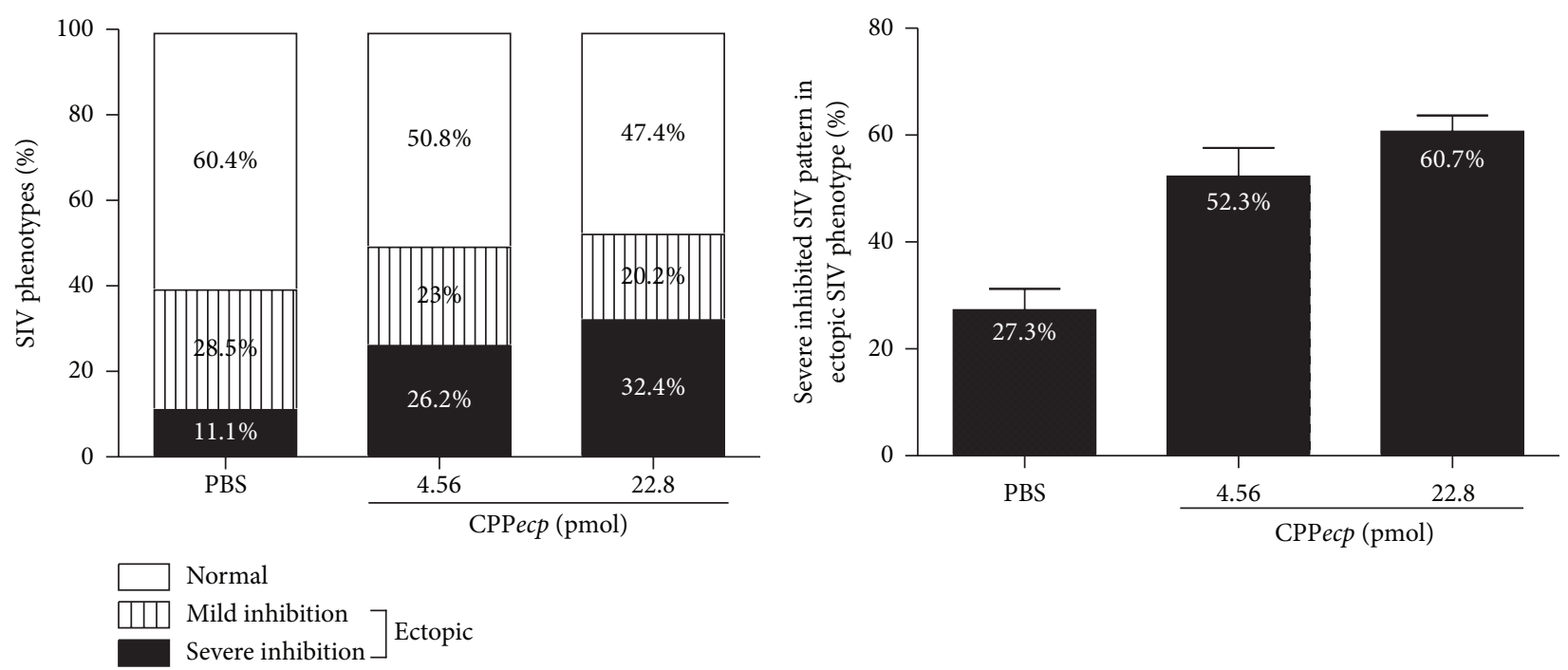

(d)

(e)

FIGURE 4: Inhibitory effect of CPPecp on angiogenesis in Tg(kdr:EGFP) zebrafish. (a) Morphology and green-labeled vessels in Tg(kdr:EGFP) zebrafish. The red rectangle represents the area of subintestinal vessel (SIV) network. Magnification: 100x. Scale bar: $400 \mu \mathrm{m}$. (b) Development of SIV network in the zebrafish yolk sac could be classified into three groups: normal, mild inhibition, and severe inhibition pattern. Magnification: 400x. Scale bar: $100 \mu \mathrm{m}$. (c) Development of SIV network in the zebrafish yolk sac at $24 \mathrm{~h}$ postinjection (hpi). Magnification: 400x. Scale bar: $100 \mu \mathrm{m}$. (d) Percentage of different SIV phenotypes in the zebrafish yolk sac at 24 hpi. (e) Percentage of severe inhibited SIV phenotype in ectopic SIV phenotype in the zebrafish yolk sac at 24 hpi. 16-20 zebrafish were used for each treatment group. The data represents means $\pm \mathrm{SD}$ (standard deviation) of three independent experiments. 


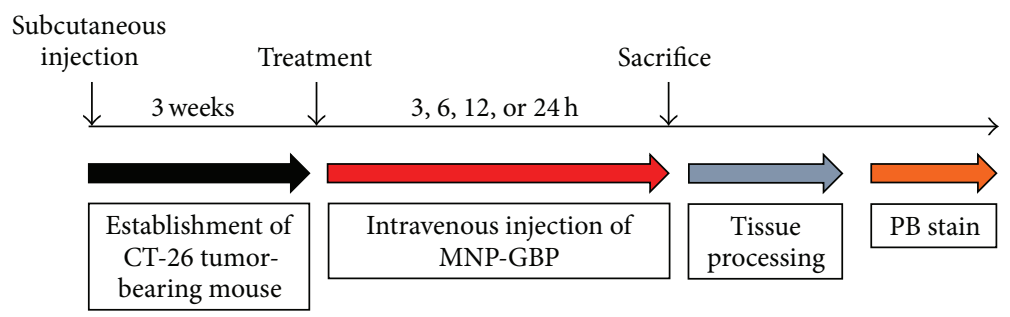

(a)

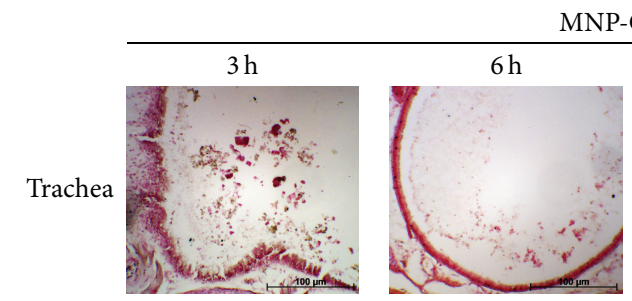

MNP-CPPecp
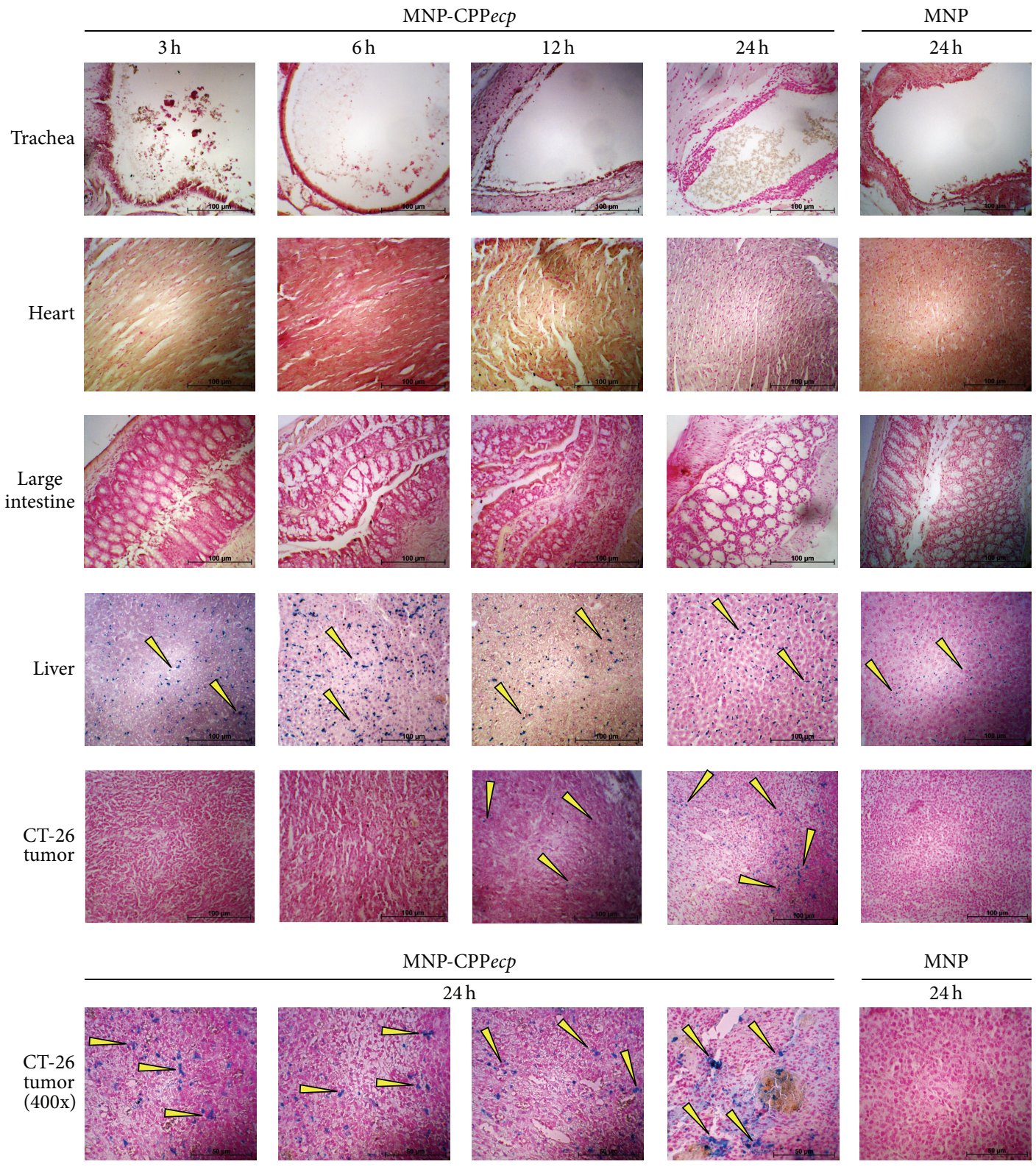

(b)

FIGURE 5: Localization of MNP-CPPecp in CT-26 tumor-bearing mouse. To investigate the biodistribution of CPPecp in vivo, CT-26 tumorbearing mice were intravenously injected with $0.06 \mathrm{emu} / \mathrm{g}$ MNP-CPPecp and sacrificed at a time point of 3, 6, 12, and 24 h after injection (a). Signal of MNP-CPPecp was visualized using Prussian blue staining to indicate ferric iron in tissue section (blue color, yellow arrow). Represented staining patterns of trachea, heart, large intestine, liver, and CT-26 tumor were shown (b). MNP injection was set as negative control. Nuclear fast red staining was set as counterstain (red color). Magnification: 200x and 400x. Scale bar: $100 \mu \mathrm{m}$ and $50 \mu \mathrm{m}$. 


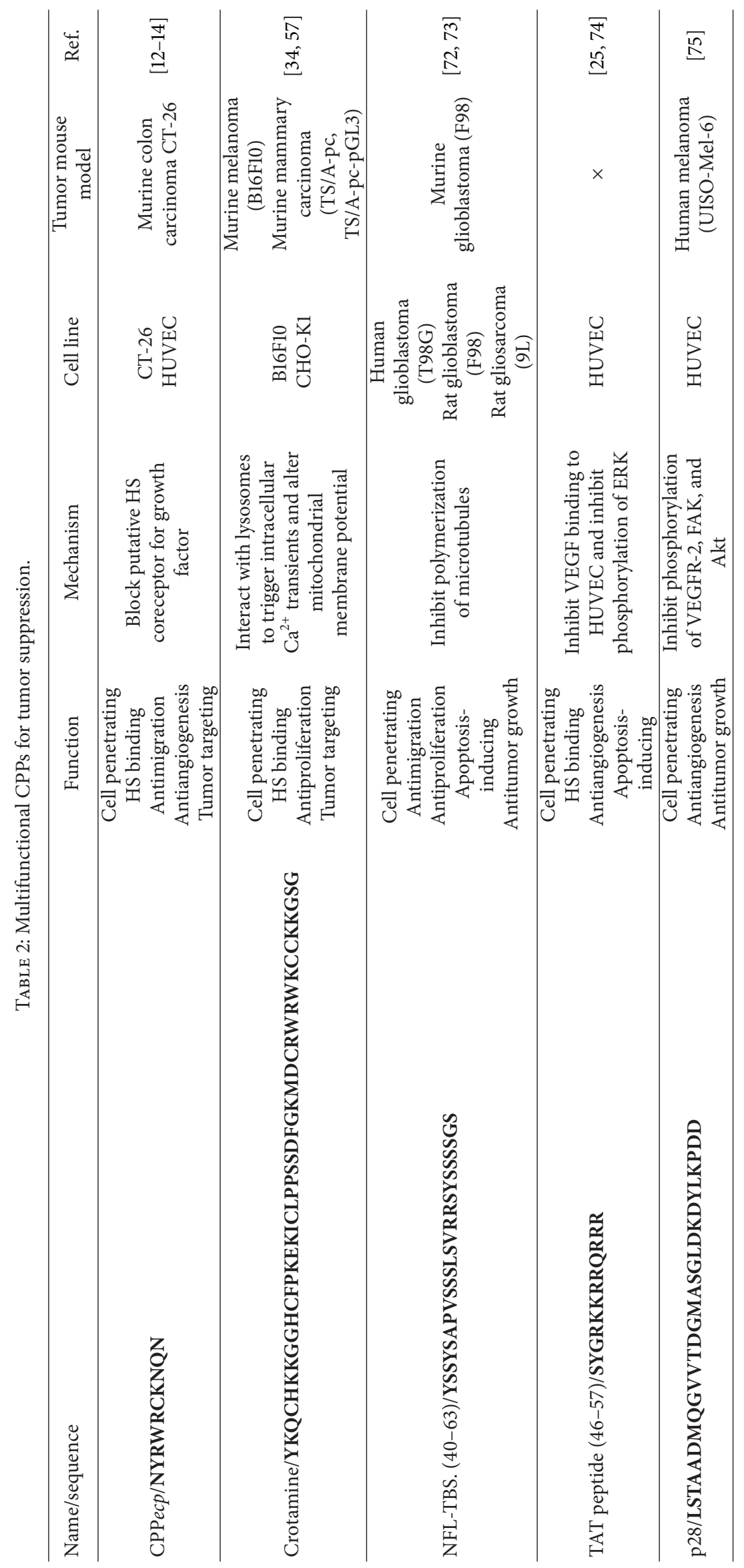


tumor site. Moreover, CPPecp containing a core RWRXK sequence demonstrates both cell penetrating and epithelial tumor targeting activities. Taken together, our HS-binding CPPecp might be feasible for further application in molecular imaging for tumor homing and selectively targeting drug delivery system.

\section{Conflict of Interests}

The authors declare that there is no conflict of interests regarding the publication of this paper.

\section{Authors' Contribution}

Chien-Jung Chen and Kang-Chiao Tsai contributed equally to this work.

\section{Acknowledgments}

The authors thank Drs. Ching-Chuan Kuo, Wun-Shaing Wayne Chang, and Yu-Ting Chou for critical comments. This work was supported by National Tsing Hua University (NTHUIOON705IEI and NTHUIOIN205IEI) and National Science Council (NSC101-2622-B-007-001-CC1 and NSC1032325-B-007-002) to M. D.-T. Chang. C.-J. Chen and P.-H. Kuo are awarded a scholarship sponsored by Apex Biotechnology Corporation, Taiwan. K.-C. Tsai is supported by Graduate Program of Biotechnology in Medicine sponsored by National Tsing Hua University and National Health Research Institute in Taiwan.

\section{References}

[1] K. R. Kampen, "The mechanisms that regulate the localization and overexpression of VEGF receptor-2 are promising therapeutic targets in cancer biology," Anti-Cancer Drugs, vol. 23, no. 4, pp. 347-354, 2012.

[2] R. Sasisekharan, Z. Shriver, G. Venkataraman, and U. Narayanasami, "Roles of heparan-sulphate glycosaminoglycans in cancer," Nature Reviews Cancer, vol. 2, no. 7, pp. 521-528, 2002.

[3] M. Adachi, T. Taki, M. Higashiyama, N. Kohno, H. Inufusa, and M. Miyake, "Significance of integrin $\alpha 5$ gene expression as a prognostic factor in node-negative non-small cell lung cancer," Clinical Cancer Research, vol. 6, no. 1, pp. 96-101, 2000.

[4] E. H. Knelson, J. C. Nee, and G. C. Blobe, "Heparan sulfate signaling in cancer," Trends in Biochemical Sciences, vol. 39, no. 6, pp. 277-288, 2014.

[5] A. Ori, M. C. Wilkinson, and D. G. Fernig, "A systems biology approach for the investigation of the heparin/heparan sulfate interactome," The Journal of Biological Chemistry, vol. 286, no. 22, pp. 19892-19904, 2011.

[6] N. Sasaki, N. Higashi, T. Taka, M. Nakajima, and T. Irimura, "Cell surface localization of heparanase on macrophages regulates degradation of extracellular matrix heparan sulfate," The Journal of Immunology, vol. 172, no. 6, pp. 3830-3835, 2004.

[7] J. Regberg, A. Srimanee, and Ü. Langel, "Applications of cellpenetrating peptides for tumor targeting and future cancer therapies," Pharmaceuticals, vol. 5, no. 9, pp. 991-1007, 2012.

[8] V. Kersemans, K. Kersemans, and B. Cornelissen, "Cell penetrating peptides for in vivo molecular imaging applications,"
Current Pharmaceutical Design, vol. 14, no. 24, pp. 2415-2427, 2008.

[9] S. Console, C. Marty, C. García-Echeverría, R. Schwendener, and K. Ballmer-Hofer, "Antennapedia and HIV transactivator of transcription (TAT) "protein transduction domains" promote endocytosis of high molecular weight cargo upon binding to cell surface glycosaminoglycans," The Journal of Biological Chemistry, vol. 278, no. 37, pp. 35109-35114, 2003.

[10] S. Deshayes, T. Plénat, P. Charnet, G. Divita, G. Molle, and F. Heitz, "Formation of transmembrane ionic channels of primary amphipathic cell-penetrating peptides. Consequences on the mechanism of cell penetration," Biochimica et Biophysica Acta, vol. 1758, no. 11, pp. 1846-1851, 2006.

[11] B. G. Bitler and J. A. Schroeder, "Anti-cancer therapies that utilize cell penetrating peptides," Recent Patents on Anti-Cancer Drug Discovery, vol. 5, no. 2, pp. 99-108, 2010.

[12] S.-L. Fang, T.-C. Fan, H.-W. Fu et al., "A novel cell-penetrating peptide derived from human eosinophil cationic protein," PLoS ONE, vol. 8, no. 3, Article ID e57318, 2013.

[13] P.-C. Lien, P.-H. Kuo, C.-J. Chen et al., "In silico prediction and in vitro characterization of multifunctional human RNase3," BioMed Research International, vol. 2013, Article ID 170398, 12 pages, 2013.

[14] C.-J. Chen, P.-H. Kuo, T.-J. Hung et al., "In vitro characterization and in vivo application of a dual functional peptide," in Proceedings of the 7th International Conference on Complex, Intelligent, and Software Intensive Systems (CISIS '13), pp. 576581, Taichung, Taiwan, July 2013.

[15] K. R. Kidd and B. M. Weinstein, "Fishing for novel angiogenic therapies," British Journal of Pharmacology, vol. 140, no. 4, pp. 585-594, 2003.

[16] G. N. Serbedzija, E. Flynn, and C. E. Willett, "Zebrafish angiogenesis: a new model for drug screening," Angiogenesis, vol. 3, no. 4, pp. 353-359, 1999.

[17] S. Y. Yang, J. L. Wu, C. H. Tso et al., "A novel quantitative immunomagnetic reduction assay for Nervous necrosis virus," Journal of Veterinary Diagnostic Investigation, vol. 24, no. 5, pp. 911-917, 2012.

[18] I. Capila and R. J. Linhardt, "Heparin-protein interactions," Angewandte Chemie-International Edition, vol. 41, no. 3, pp. 391-412, 2002.

[19] C. Combet, C. Blanchet, C. Geourjon, and G. Deléage, "NPS@: network protein sequence analysis," Trends in Biochemical Sciences, vol. 25, no. 3, pp. 147-150, 2000.

[20] J. L. Sussman, E. E. Abola, D. Lin, J. Jiang, N. O. Manning, and J. Prilusky, "The protein data bank: Bridging the gap between the sequence and 3D structure world," Genetica, vol. 106, no. 1-2, pp. 149-158, 1999.

[21] Y. G. Choi and A. L. N. Rao, "Molecular studies on bromovirus capsid protein: VII. Selective packaging of BMV RNA4 by specific N-terminal arginine residues," Virology, vol. 275, no. 1, pp. 207-217, 2000.

[22] S. Futaki, T. Suzuki, W. Ohashi et al., "Arginine-rich peptides. An abundant source of membrane-permeable peptides having potential as carriers for intracellular protein delivery," Journal of Biological Chemistry, vol. 276, no. 8, pp. 5836-5840, 2001.

[23] J. P. M. Langedijk, "Translocation activity of C-terminal domain of pestivirus Erns and ribotoxin L3 loop," Journal of Biological Chemistry, vol. 277, no. 7, pp. 5308-5314, 2002.

[24] L. Chaloin, P. Vidal, P. Lory et al., "Design of carrier peptideoligonucleotide conjugates with rapid membrane translocation 
and nuclear localization properties," Biochemical and Biophysical Research Communications, vol. 243, no. 2, pp. 601-608, 1998.

[25] E. Vivès, P. Brodin, and B. Lebleu, "A truncated HIV-1 Tat protein basic domain rapidly translocates through the plasma membrane and accumulates in the cell nucleus," Journal of Biological Chemistry, vol. 272, no. 25, pp. 16010-16017, 1997.

[26] J. S. Wadia, R. V. Stan, and S. F. Dowdy, “Transducible TAT-HA fusogenic peptide enhances escape of TAT-fusion proteins after lipid raft macropinocytosis," Nature Medicine, vol. 10, no. 3, pp. 310-315, 2004.

[27] T. Sugita, T. Yoshikawa, Y. Mukai et al., "Comparative study on transduction and toxicity of protein transduction domains," British Journal of Pharmacology, vol. 153, no. 6, pp. 1143-1152, 2008.

[28] S. Kameyama, M. Horie, T. Kikuchi et al., "Acid wash in determining cellular uptake of fab/cell-permeating peptide conjugates," Biopolymers, vol. 88, no. 2, pp. 98-107, 2007.

[29] G. Elliott and P. O'Hare, "Intercellular trafficking and protein delivery by a herpesvirus structural protein," Cell, vol. 88, no. 2 , pp. 223-233, 1997.

[30] F. J. Byfield, Q. Wen, K. Leszczyńska et al., "Cathelicidin LL37 peptide regulates endothelial cell stiffness and endothelial barrier permeability," The American Journal of Physiology-Cell Physiology, vol. 300, no. 1, pp. C105-C112, 2011.

[31] S. Pochet, S. Tandel, S. Querriére et al., "Modulation by LL37 of the responses of salivary glands to purinergic agonists," Molecular Pharmacology, vol. 69, no. 6, pp. 2037-2046, 2006.

[32] G. Drin, S. Cottin, E. Blanc, A. R. Rees, and J. Temsamani, "Studies on the internalization mechanism of cationic cellpenetrating peptides," The Journal of Biological Chemistry, vol. 278, no. 33, pp. 31192-31201, 2003.

[33] M. Magzoub, S. Sandgren, P. Lundberg et al., "N-terminal peptides from unprocessed prion proteins enter cells by macropinocytosis," Biochemical and Biophysical Research Communications, vol. 348, no. 2, pp. 379-385, 2006.

[34] F. D. Nascimento, M. A. F. Hayashi, A. Kerkis et al., "Crotamine mediates gene delivery into cells through the binding to heparan sulfate proteoglycans," The Journal of Biological Chemistry, vol. 282, no. 29, pp. 21349-21360, 2007.

[35] Z. Fajloun, R. Kharrat, L. Chen et al., "Chemical synthesis and characterization of maurocalcine, a scorpion toxin that activates $\mathrm{Ca}^{2+}$ release channel/ryanodine receptors," FEBS Letters, vol. 469, no. 2-3, pp. 179-185, 2000.

[36] A. Mosbah, R. Kharrat, Z. Fajloun et al., "A new fold in the scorpion toxin family, associated with an activity on a ryanodine-sensitive calcium channel," Proteins, vol. 40, no. 3, pp. 436-442, 2000.

[37] E. Vives, "Cellular utake of the Tat peptide: an endocytosis mechanism following ionic interactions," Journal of Molecular Recognition, vol. 16, no. 5, pp. 265-271, 2003.

[38] M. Tyagi, M. Rusnati, M. Presta, and M. Giacca, "Internalization of HIV-1 tat requires cell surface heparan sulfate proteoglycans," The Journal of Biological Chemistry, vol. 276, no. 5, pp. 32543261, 2001.

[39] T.-W. Pai, M. D.-T. Chang, W.-S. Tzou et al., "REMUS: a tool for identification of unique peptide segments as epitopes," Nucleic Acids Research, vol. 34, pp. W198-W201, 2006.

[40] D. Jha, R. Mishra, S. Gottschalk et al., "CyLoP-1: a novel cysteine-rich cell-penetrating peptide for cytosolic delivery of cargoes," Bioconjugate Chemistry, vol. 22, no. 3, pp. 319-328, 2011.
[41] G. Dom, C. Shaw-Jackson, C. Matis et al., "Cellular uptake of Antennapedia Penetratin peptides is a two-step process in which phase transfer precedes a tryptophan-dependent translocation," Nucleic Acids Research, vol. 31, no. 2, pp. 556-561, 2003.

[42] H. Park, Y. Kim, Y. Lim, I. Han, and E.-S. Oh, "Syndecan-2 mediates adhesion and proliferation of colon carcinoma cells," The Journal of Biological Chemistry, vol. 277, no. 33, pp. 29730 29736, 2002.

[43] K. Nackaerts, E. Verbeken, G. Deneffe, B. Vanderschueren, M. Demedts, and G. David, "Heparan sulfate proteoglycan expression in human lung-cancer cells," International Journal of Cancer, vol. 74, no. 3, pp. 335-345, 1997.

[44] R. D. Sanderson, "Heparan sulfate proteoglycans in invasion and metastasis," Seminars in Cell and Developmental Biology, vol. 12, no. 2, pp. 89-98, 2001.

[45] S. Hibino, M. Shibuya, M. P. Hoffman et al., "Laminin $\alpha 5$ chain metastasis- and angiogenesis-inhibiting peptide blocks fibroblast growth factor 2 activity by binding to the heparan sulfate chains of CD44," Cancer Research, vol. 65, no. 22, pp. 10494-10501, 2005.

[46] M. M. Fuster, L. Wang, J. Castagnola et al., "Genetic alteration of endothelial heparan sulfate selectively inhibits tumor angiogenesis," The Journal of Cell Biology, vol. 177, no. 3, pp. 539-549, 2007.

[47] L. Jakobsson, J. Kreuger, K. Holmborn et al., "Heparan sulfate in trans potentiates VEGFR-mediated angiogenesis," Developmental Cell, vol. 10, no. 5, pp. 625-634, 2006.

[48] L. Lamalice, F. Le Boeuf, and J. Huot, "Endothelial cell migration during angiogenesis," Circulation Research, vol. 100, no. 6, pp. 782-794, 2007.

[49] S. Hibino, M. Shibuya, J. A. Engbring, M. Mochizuki, M. Nomizu, and H. K. Kleinman, "Identification of an active site on the laminin $\alpha 5$ chain globular domain that binds to CD44 and inhibits malignancy," Cancer Research, vol. 64, no. 14, pp. 4810-4816, 2004.

[50] T.-Y. Lee, J. Folkman, and K. Javaherian, "HSPG-Binding peptide corresponding to the exon 6a-encoded domain of VEGF inhibits tumor growth by blocking angiogenesis in Murine model," PLoS ONE, vol. 5, no. 4, Article ID e9945, 2010.

[51] S. Nicoli, G. De Sena, and M. Presta, "Fibroblast growth factor 2induced angiogenesis in zebrafish: the zebrafish yolk membrane (ZFYM) angiogenesis assay," Journal of Cellular and Molecular Medicine, vol. 13, no. 8, pp. 2061-2068, 2009.

[52] M.-W. Kuo, C.-H. Wang, H.-C. Wu, S.-J. Chang, and Y.-J. Chuang, "Soluble THSD7A is an N-glycoprotein that promotes endothelial cell migration and tube formation in angiogenesis," PLoS ONE, vol. 6, no. 12, Article ID e29000, 2011.

[53] R. Kumar, I. Roy, T. Y. Ohulchanskky et al., "In vivo biodistribution and clearance studies using multimodal organically modified silica nanoparticles," ACS Nano, vol. 4, no. 2, pp. 699708, 2010.

[54] S. Nagayama, K.-I. Ogawara, Y. Fukuoka, K. Higaki, and T. Kimura, "Time-dependent changes in opsonin amount associated on nanoparticles alter their hepatic uptake characteristics," International Journal of Pharmaceutics, vol. 342, no. 1-2, pp. 215221, 2007.

[55] B. Zhang, B. Yang, C. Zhai, B. Jiang, and Y. Wu, "The role of exendin-4-conjugated superparamagnetic iron oxide nanoparticles in beta-cell-targeted MRI," Biomaterials, vol. 34, no. 23, pp. 5843-5852, 2013. 
[56] D. Sarko, B. Beijer, R. G. Boy et al., "The pharmacokinetics of cell-penetrating peptides," Molecular Pharmaceutics, vol. 7, no. 6, pp. 2224-2231, 2010.

[57] F. D. Nascimento, L. Sancey, A. Pereira et al., "The natural cellpenetrating peptide crotamine targets tumor tissue in vivo and triggers a lethal calcium-dependent pathway in cultured cells," Molecular Pharmaceutics, vol. 9, no. 2, pp. 211-221, 2012.

[58] D. Görlich and I. W. Mattaj, "Nucleocytoplasmic transport," Science, vol. 271, no. 5255, pp. 1513-1518, 1996.

[59] D. Kalderon, B. L. Roberts, W. D. Richardson, and A. E. Smith, "A short amino acid sequence able to specify nuclear location," Cell, vol. 39, no. 3, pp. 499-509, 1984.

[60] D. A. Jans, D. A. Jans, P. Jans, and P. Jans, "Negative charge at the casein kinase II site flanking the nuclear localization signal of the SV40 large T-antigen is mechanistically important for enhanced nuclear import," Oncogene, vol. 9, no. 10, pp. 29612968, 1994.

[61] D. Derossi, A. H. Joliot, G. Chassaing, and A. Prochiantz, "The third helix of the Antennapedia homeodomain translocates through biological membranes," The Journal of Biological Chemistry, vol. 269, no. 14, pp. 10444-10450, 1994.

[62] T.-C. Fan, H.-T. Chang, I.-W. Chen, H.-Y. Wang, and M. D.T. Chang, "A heparan sulfate-facilitated and raft-dependent macropinocytosis of eosinophil cationic protein," Traffic, vol. 8, no. 12, pp. 1778-1795, 2007.

[63] M. C. Schmidt, B. Rothen-Rutishauser, B. Rist et al., "Translocation of human calcitonin in respiratory nasal epithelium is associated with self-assembly in lipid membrane," Biochemistry, vol. 37, no. 47, pp. 16582-16590, 1998.

[64] N. Sakamoto and A. S. Rosenberg, "Apolipoprotein B binding domains: evidence that they are cell-penetrating peptides that efficiently deliver antigenic peptide for cross-presentation of cytotoxic T cells," Journal of Immunology, vol. 186, no. 8, pp. 5004-5011, 2011.

[65] S. Lang, B. Rothen-Rutishauser, J. C. Perriard, M. C. Schmidt, and H. P. Merkle, "Permeation and pathways of human calcitonin (hCT) across excised bovine nasal mucosa," Peptides, vol. 19, no. 3, pp. 599-607, 1998.

[66] A. Elmquist, M. Lindgren, T. Bartfai, and Ü. Langel, "Vecadherin-derived cell-penetrating peptide, pVEC with carrier functions," Experimental Cell Research, vol. 269, no. 2, pp. 237244, 2001.

[67] E. Eiríksdóttir, I. Mäger, T. Lehto, S. El Andaloussi, and Ü. Langel, "Cellular internalization kinetics of (luciferin-)cellpenetrating peptide conjugates," Bioconjugate Chemistry, vol. 21, no. 9, pp. 1662-1672, 2010.

[68] I. Mäger, E. Eiríksdóttir, K. Langel, S. EL Andaloussi, and Ü. Langel, "Assessing the uptake kinetics and internalization mechanisms of cell-penetrating peptides using a quenched fluorescence assay," Biochimica et Biophysica Acta, vol. 1798, no. 3, pp. 338-343, 2010.

[69] F. Duchardt, I. R. Ruttekolk, W. P. R. Verdurmen et al., "A cell-penetrating peptide derived from human lactoferrin with conformation-dependent uptake efficiency," The Journal of Biological Chemistry, vol. 284, no. 52, pp. 36099-36108, 2009.

[70] H. Noguchi, S. Matsumoto, T. Okitsu et al., "PDX-1 protein is internalized by lipid raft-dependent macropinocytosis," Cell Transplantation, vol. 14, no. 9, pp. 637-645, 2005.

[71] F. J. Byfield, Q. Wen, K. Leszczyńska et al., "Cathelicidin LL37 peptide regulates endothelial cell stiffness and endothelial barrier permeability," American Journal of Physiology-Cell Physiology, vol. 300, no. 1, pp. C105-C112, 2011.
[72] R. Berges, J. Balzeau, A. C. Peterson, and J. Eyer, "A tubulin binding peptide targets glioma cells disrupting their microtubules, blocking migration, and inducing apoptosis," Molecular Therapy, vol. 20, no. 7, pp. 1367-1377, 2012.

[73] C. Lépinoux-Chambaud and J. Eyer, “The NFL-TBS.40-63 anti-glioblastoma peptide enters selectively in glioma cells by endocytosis," International Journal of Pharmaceutics, vol. 454, no. 2, pp. 738-747, 2013.

[74] H. Jia, M. Lohr, S. Jezequel et al., "Cysteine-rich and basic domain HIV-1 Tat peptides inhibit angiogenesis and induce endothelial cell apoptosis," Biochemical and Biophysical Research Communications, vol. 283, no. 2, pp. 469-479, 2001.

[75] R. R. Mehta, T. Yamada, B. N. Taylor et al., "A cell penetrating peptide derived from azurin inhibits angiogenesis and tumor growth by inhibiting phosphorylation of VEGFR-2, FAK and Akt," Angiogenesis, vol. 14, no. 3, pp. 355-369, 2011. 

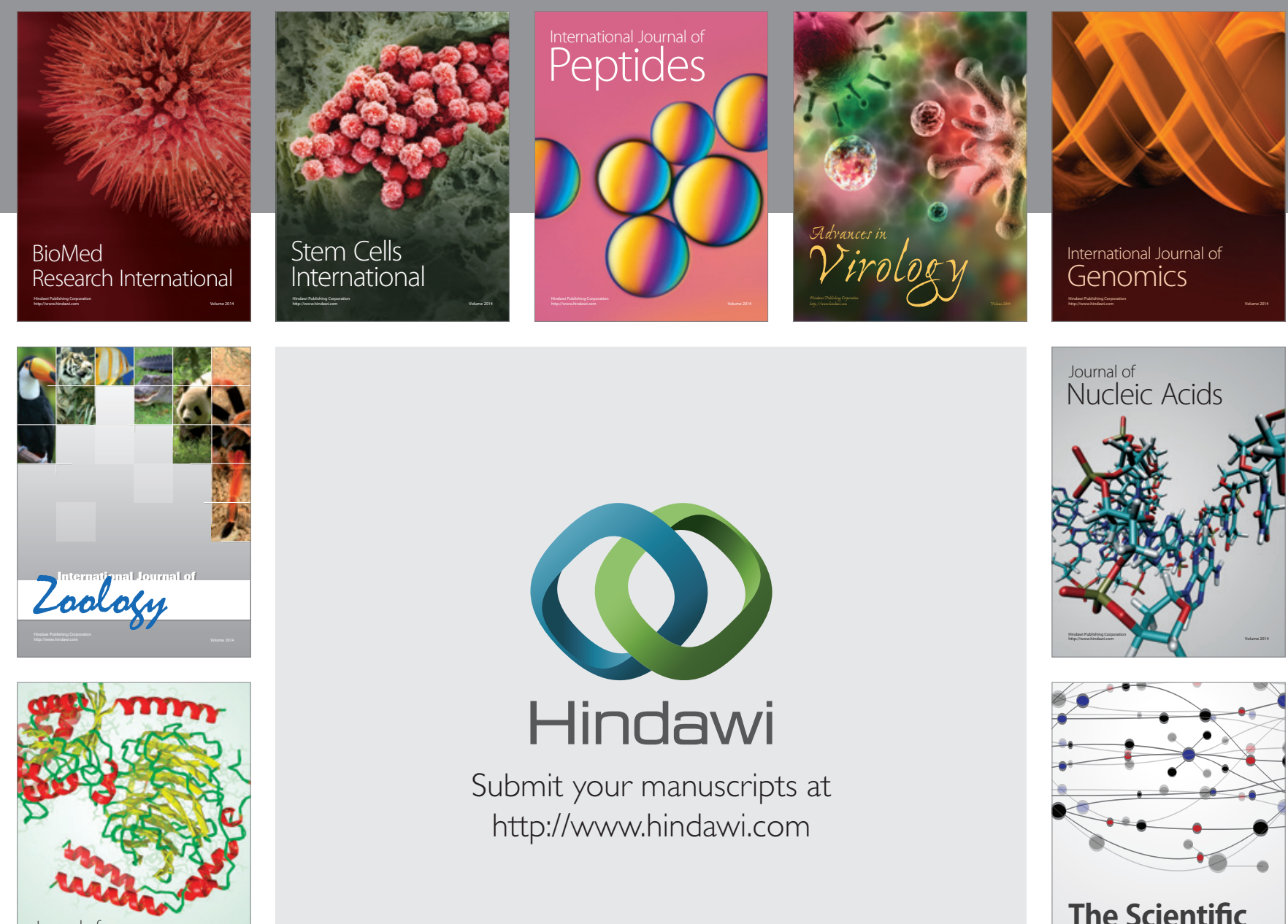

Submit your manuscripts at

http://www.hindawi.com

Journal of
Signal Transduction
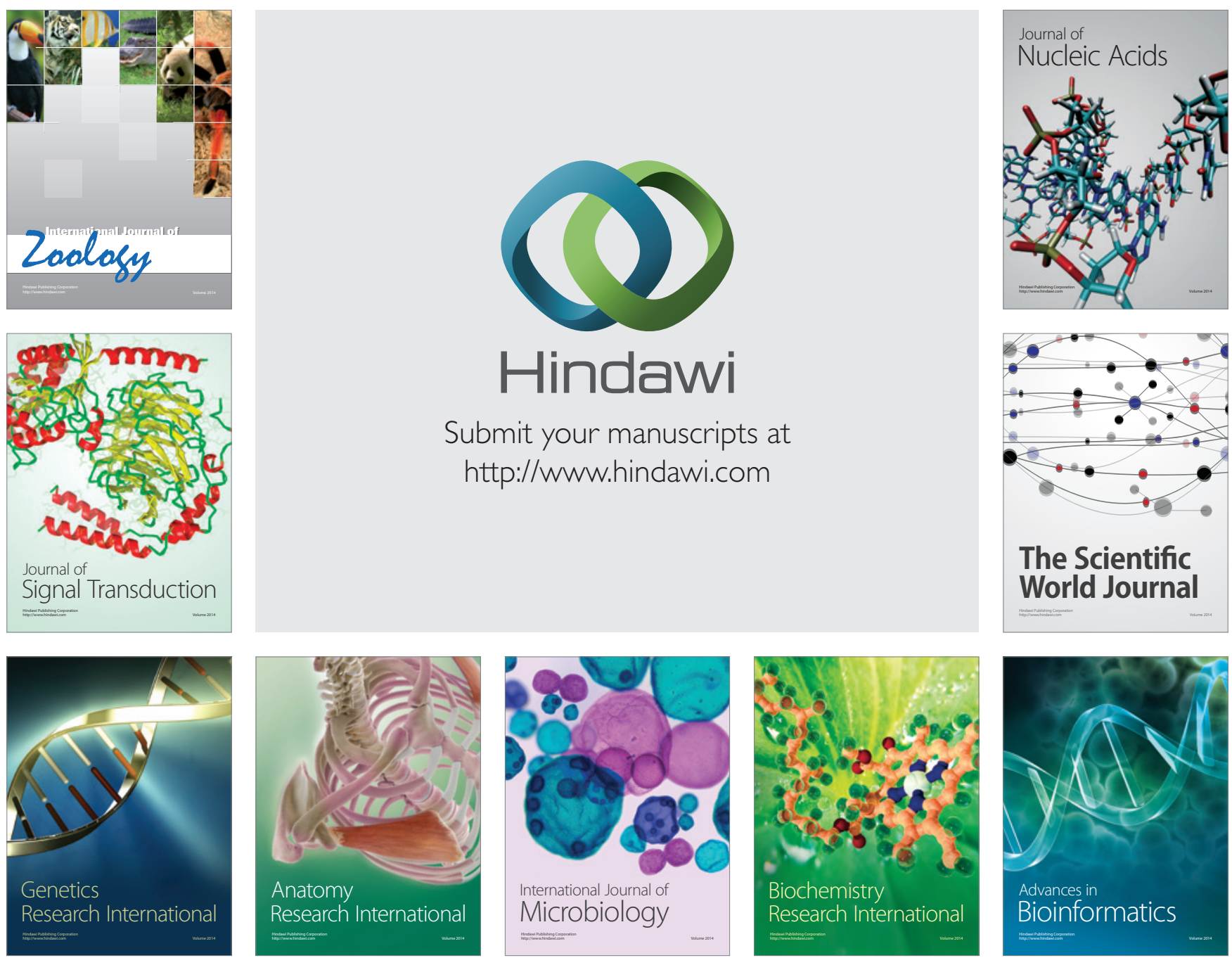

The Scientific World Journal
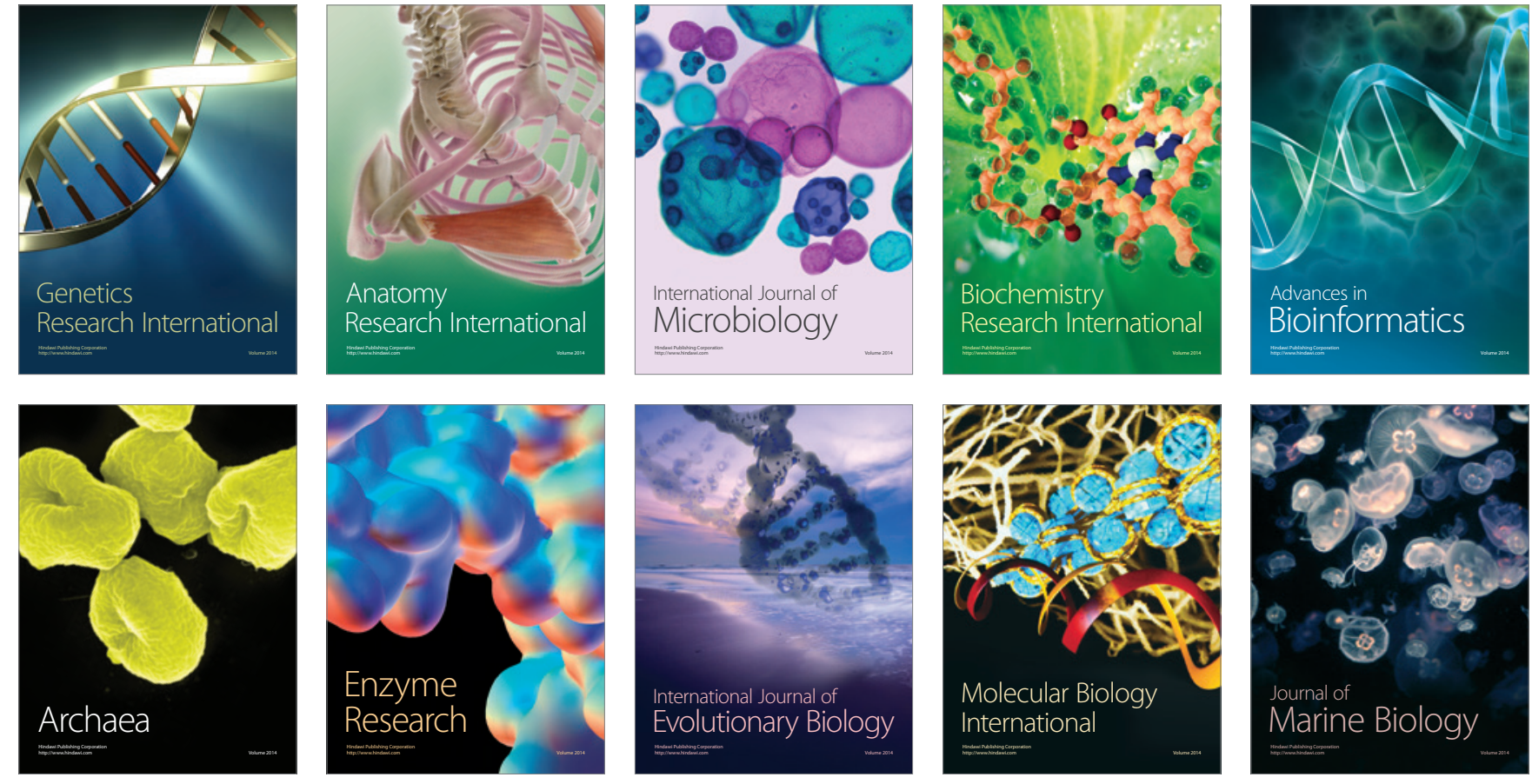